Uniwersytet im. Adama Mickiewicza, Poznań

\title{
Przeszczep mózgu - dylematy prawne, społeczne i deontologiczne
}

Celem niniejszego opracowania są - trzeba przyznać na razie dość futu-
rystyczne - rozważania dotyczące konsekwencji prawnych, społecz-
nych, etycznych postępu technologicznego w medycynie, którego właśnie
(lub za chwilę) jesteśmy świadkami. Żeby pokazać istotę problemu autor
chciałby skupić się tylko na jednej z płaszczyzn tej ,rewolucji” medycz-
no-technicznej, jaka może być niebawem możliwość przeszczepu mózgu.
Trzeba od razu dodać, że inne aspekty tych zmian, takie jak chociażby
problemy wspomaganego rozrodu, klonowania, inżynierii genetycznej,
stosowania niektórych środków psychotropowych są nie mniej kontro-
wersyjne z punktu widzenia deontologicznego i prawnego. Zgodzić nale-
ży się z poglądem, że rewolucja w medycynie, oprócz tego, że wpłynie
z pewnością na losy jednostek, może mieć także konsekwencje polityczne,
chociażby w kontekście możliwości świadomej zmiany natury ludzkiej ${ }^{1}$.

Pierwszą kwestią, którą należałoby rozstrzygnąć jest problem terminologiczny, a mianowicie czy mówiąc o przeszczepie mózgu, należy rozważać możliwości przeszczepu tego właśnie organu, czy też chodzi o przeszczep ciała do mózgu. Jest to o tyle istotne, iż rozstrzyga podstawowy dylemat związany z omawianym tu zagadnieniem, tzn. czy w takim przypadku można mówić o ciagłości życia ludzkiego oraz czy tożsamość jednostki zostaje zachowana, a jeżeli tak to ,związana” będzie z ciałem czy mózgiem.

Wcześniej jednak należy zadać pytanie czy z punktu widzenia technologii medycznej jest to obecnie w ogóle możliwe. Pierwsze próby takich zabiegów były oczywiście eksperymentami na zwierzętach. Pierwsze doniesienia pochodzą już z roku 1908, kiedy próbowano przeszczepić głowę psa. Tak naprawdę udało się jedynie zachować krążenie krwi i to bardzo krótko, bo przez około 20 minut $^{2}$. Kolejne wzmianki pochodzą ze Związ-

1 F. Fukuyama, Koniec człowieka, Kraków 2004, s. 33.

2 Patrz szerzej hasło Head transplant w encyklopedii Wikipedia, www.en.wikipedia.org/wiki/head_transplant. 
ku Radzieckiego, kiedy to Władymir Demikhov dokonał podobnego zabiegu tylko z dużo lepszym skutkiem ${ }^{3}$. W 1959 r. podobne próby podjęto w Chinach ${ }^{4}$. Niezłym sukcesem zakończył się podobny eksperyment w Stanach Zjednoczonych, a konkretnie w Case Western Reserve University School of Medicine w Cleveland w Ohio. Otóż neurochirurg Robert J. White podjął się próby przeszczepienia głowy jednej małpy drugiej małpie. Wynik był o tyle zaskakujący, iż zwierzę z przeszczepioną głową (a raczej: przeszczepiona głowa!) zachowało zmysły powonienia, smaku, słuch i widzenie. Eksperyment powtórzono w 2001 r. $^{5}$

We wszystkich tych przypadkach podstawowym problemem medycznym, trudnym obecnie do przezwyciężenia, jest konieczność przecięcia w tego rodzaju zabiegach rdzenia kręgowego, czego wedle obecnej wiedzy medycznej nie udaje się naprawić. Optymistycznie brzmią jednak doniesienia naukowe, jak chociażby te pochodzące $\mathrm{z}$ Winstar Institute of the University of Pensylvania przekonywujące, iż tego rodzaju eksperyment na myszach zakończył się sukcesem ${ }^{6}$.

Jeszcze innym problemem, który także może przynieść szereg problemów prawnych, społecznych oraz etycznych, jest przeszczep części mózgu. W 1982 r., dr Dorothy T. Krieger, kierownik endokrynologii w Mount Sinai Medical Center w Nowym Jorku, odnotowała sukces w przeszczepie części mózgu u myszy ${ }^{7}$.

Gdy chodzi o eksperymenty na ludziach, to można przywołać eksperyment z 30 marca 1982 r. w Karolinska Hospitalet w Sztokholmie, gdzie dokonano przeszczepu tkanki do mózgu 55 letniego mężczyzny cierpiącego na chorobę Parkinsona ${ }^{8}$. Jest to dzisiaj rozważane jako jedna z metod leczenia tej właśnie choroby9

3 Ibidem a także w przywołanej tu pozycji M. Roach, Stiff: The Curious Lives of Human Cadavers, s. 206-210.

4 Ibidem.

5 Ibidem.

6 Ibidem. Patrz także P. Pietsch, C. W. Schneider, Brain Transplantation in Salamanders: An Approach to Memory Transfer, „Brain Research” 1969, vol. 14, s. 707-714.

7 Patrz szerzej hasło w Wikipedii: Whole-body transplant, tekst dostępny na stronach internetowych www.en.wikipedia.org/wiki/Brain_transplant.

8 K. E. Morrison, Brain transplantation - still fantasy?, ,Journal of the Royal Society of Medicine", vol. 80, July 1987, s. 441-444.

9 Patrz szerzej H. Q. Rana, The Modern Day Brain Transplant: An End to Parkinsonism?, www.serendip.brynmawr.edu./bb/neuro/neuro01/web2/Rana.html. 
Jednak niemalże od początku podobnych prób, rodziły się wątpliwości co do etycznej strony takich eksperymentów ${ }^{10}$. Dylematy powróciły nawet wówczas, gdy po raz pierwszy udało się dokonać przeszczepu twarzy $^{11}$. W tym przypadku pojawiły się bowiem już wątpliwości co do zmiany tożsamości biorcy, a przecież ta operacja ograniczała się tylko do przeszczepu skóry, tkanki podskórnej i może jeszcze chrząstek nosa ${ }^{12}$.

Należałoby jednak zastanowić się, czy w świetle obecnego stanu prawnego obowiązującego w Polsce w ogóle istnieje możliwość transplantacji tego organu i jakie mogą z tego wynikać konsekwencje. Przypomnieć na wstępie należy, że Konstytucja Rzeczpospolitej Polskiej z dnia 2 kwietnia 1997 r. $^{13}$ w art. 38 zapewnia każdemu człowiekowi prawną ochronę życia. Z kolei art. 39 ustawy zasadniczej stanowi, iż nikt nie może być poddany eksperymentom naukowym, w tym medycznym, bez dobrowolnie wyrażonej zgody. Jednak w uzasadnieniu orzeczenia Trybunału Konstytucyjnego z dnia 28 maja 1997 r. ${ }^{14}$ podkreślono, iż ,podstawowym przepisem, z którego należy wyprowadzać konstytucyjną ochronę życia ludzkiego jest jednak art. 1 przepisów konstytucyjnych, w szczególności zaś zasada demokratycznego państwa prawnego. Państwo takie realizuje

10 Patrz szerzej R. Newcombe, „British Medical Journal”, 20 stycznia 1968, s. 178; Brain Transplants: New Ethical Frontier?, 30 maj 2006, www.hollandhealthcare.com/healthcare/2006/05brain_transplan.html.

11 Po raz pierwszy zabieg taki przeprowadzono we Francji 2005 r. 38-letniej kobiecie przeszczepiono fragmenty twarzy obejmujące nos, wargi i podbródek, pobrany od osoby w stanie śmierci mózgowej. Prasa donosiła wówczas (m.in. „Time” i „New York Times"), iż pacjentka była niezrównoważona psychicznie, a jej obrażenia powstały w wyniku pogryzienia przez psa, w czasie kiedy kobieta próbowała popełnić samobójstwo. Informacje te jednak zdementowano (patrz szerzej tekst na stronie www.biomedical.pl). Ostatnio w 2008 r. zabieg taki w USA w klinice w Cleveland przeprowadziła dr Siemionow. Operator w wywiadzie dla „Gazety Wyborczej” z 2005 r. na pytanie kim będzie osoba z przeszczepioną twarzą? Odpowiedziała: „Pozostanie sobą. Słyszę czasem zarzut, że po przeszczepie twarzy pacjent będzie już kimś innym, że chcemy dokonać transferu tożsamości. W takim razie kim była ta osoba po urazie, który kompletnie zmienił wygląd jej twarzy? A kim była po operacji rekonstruującej jej rysy?" Patrz: www.wyborcza.pl/1,75480,2875632.html.

12 Patrz więcej na ten temat: From face to brain transplant. Stem Cell Breakthrough, 2005, www.brainethics.wordpress.com/2005/12/06from-face-to-brain-transplant/.

13 Dz. U. Nr 78, poz. 483 z późn. zm.

14 Orzeczenie Trybunału Konstytucyjnego z dnia 28 maja 1997 r., sygn. K. 26/96, opublik. „LexPolonica” nr 320490 OTK ZU 1997/2 poz. 19, „Państwo i Prawo” 1998, nr 1 , s. 88 . 
się bowiem wyłącznie jako wspólnota ludzi i tylko ludzie mogą być właściwymi podmiotami praw i obowiązków stanowionych w takim państwie. Podstawowym przymiotem człowieka jest jego życie. Pozbawienie życia unicestwia więc równocześnie człowieka, jako podmiot praw i obowiązków. Jeżeli treścią zasady państwa prawa jest zespół podstawowych dyrektyw wyprowadzanych $\mathrm{z}$ istoty demokratycznie stanowionego prawa, a gwarantujących minimum jego sprawiedliwości, to pierwszą taką dyrektywą musi być respektowanie w państwie prawa wartości, bez której wykluczona jest wszelka podmiotowość prawna, tj. życia ludzkiego od początków jego powstania. Demokratyczne państwo prawa jako naczelną wartość stawia człowieka i dobra dla niego najcenniejsze. Dobrem takim jest życie, które w demokratycznym państwie prawa musi pozostawać pod ochroną konstytucyjną w każdym stadium jego rozwoju"15.

Warto także przyjrzeć się ustawie z dnia 1 lipca 2005 r. o pobieraniu, przechowywaniu i przeszczepianiu komórek, tkanek i narządów. Zdefiniowano tu m.in. terminy jak ,narząd” i ,ppobieranie”. To pierwsze pojęcie oznacza wyodrębnioną i istotną część ludzkiego ciała, zbudowaną z różnych tkanek, zdolną do utrzymywania swojej struktury, ukrwienia i możliwości pełnienia autonomicznych funkcji fizjologicznych, a to drugie czynności, w wyniku których komórki, tkanki lub narządy są pozyskiwane w celach diagnostycznych, leczniczych, naukowych lub dydaktycznych. Niewątpliwie w świetle powyższej definicji mózg będzie organem, a transplantacja pobieraniem. Ustawa wprowadza zasadę zakazu przyjmowania zapłaty lub innej korzyści majątkowej w zamian za pobrane od dawcy komórki, tkanki lub narządy. Ustawodawca sprecyzował jednocześnie, iż zwrot kosztów ${ }^{16}$ pobrania, przechowywania, przetwarzania, sterylizacji, dystrybucji i przeszczepiania nie będą uchodzić za korzyść majątkową. Kolejną zasadą wprowadzoną w komentowanym akcie normatywnym jest reguła, iż komórki, tkanki i narządy mogą być pobierane ze zwłok ludzkich w celach diagnostycznych, leczniczych, naukowych

15 Ibidem.

16 Zgodnie z art. 3 ust. 3 ustawy do kosztów pobrania, przechowywania, przetwarzania, sterylizacji, dystrybucji i przeszczepiania komórek, tkanek lub narządów zalicza się koszty obejmujące pobranie komórek, tkanek i narządów od dawcy, pobyt potencjalnego żywego dawcy w szpitalu, wydanie opinii lekarskich, zabiegu pobrania, badań laboratoryjnych przed i po pobraniu, hodowanie komórek do przeszczepiania, transport z zakładu opieki zdrowotnej lub do tego zakładu, w którym ma być dokonany przeszczep oraz przechowywanie, przetwarzanie i sterylizacja. 
i dydaktycznych, jednak pod warunkiem, iż osoba zmarła nie wyraziła za życia sprzeciwu ${ }^{17}$. Dawcą może być jednak także osoba żywa pod warunkiem spełnienia szeregu wymogów określonych w art. 12 ustawy ${ }^{18}$, w tym

17 W przypadku małoletniego lub innej osoby, która nie ma pełnej zdolności do czynności prawnych, sprzeciw może wyrazić za ich życia przedstawiciel ustawowy. W przypadku małoletniego powyżej lat szesnastu sprzeciw może wyrazić również ten małoletni. Zasad tych nie stosuje się w przypadku pobierania komórek, tkanek i narządów w celu rozpoznania przyczyny zgonu i oceny w czasie sekcji zwłok postępowania leczniczego. Zgodnie z art. 6 ustawy sprzeciw wyraża się w formie: 1) wpisu w centralnym rejestrze sprzeciwów na pobranie komórek, tkanek i narządów ze zwłok ludzkich; 2) oświadczenia pisemnego zaopatrzonego we własnoręczny podpis; 3) oświadczenia ustnego złożonego w obecności co najmniej dwóch świadków, pisemnie przez nich potwierdzonego.

$18 \mathrm{~W}$ art. 1 ust. 1 ustawy stanowi, iż komórki, tkanki lub narządy mogą być pobierane od żywego dawcy w celu przeszczepienia innej osobie, przy zachowaniu następujących warunków:

1) pobranie następuje na rzecz krewnego w linii prostej, rodzeństwa, osoby przysposobionej lub małżonka oraz, z zastrzeżeniem art. 13, na rzecz innej osoby, jeżeli uzasadniają to szczególne względy osobiste;

2) w odniesieniu do pobrania szpiku lub innych regenerujących się komórek lub tkanek, pobranie może nastapić również na rzecz innej osoby niż wymieniona w pkt 1 ;

3) zasadność i celowość pobrania i przeszczepienia komórek, tkanek lub narządów od określonego dawcy ustalają lekarze pobierający i przeszczepiający je określonemu biorcy na podstawie aktualnego stanu wiedzy medycznej;

4) pobranie zostało poprzedzone niezbędnymi badaniami lekarskimi ustalającymi, czy ryzyko zabiegu nie wykracza poza przewidywane granice dopuszczalne dla tego rodzaju zabiegów i nie upośledzi w istotny sposób stanu zdrowia dawcy;

5) kandydat na dawcę został przed wyrażeniem zgody szczegółowo, pisemnie poinformowany o rodzaju zabiegu, ryzyku związanym z tym zabiegiem i o dających się przewidzieć następstwach dla jego stanu zdrowia w przyszłości przez lekarza wykonującego zabieg oraz przez innego lekarza niebiorącego bezpośredniego udziału w pobieraniu i przeszczepieniu komórek, tkanek lub narządu;

6) kobieta ciężarna może być kandydatem na dawcę jedynie komórek i tkanek; ryzyko, o którym mowa w pkt 4 i 5, określa się w tym przypadku również dla mającego się urodzić dziecka przy udziale lekarza ginekologa-położnika i neonatologa;

7) kandydat na dawcę ma pełną zdolność do czynności prawnych i wyraził dobrowolnie przed lekarzem pisemną zgodę na pobranie komórek, tkanek lub narządu w celu ich przeszczepienia określonemu biorcy; wymóg określenia biorcy przeszczepu nie dotyczy pobrania szpiku lub innej regenerującej się komórki i tkanki;

8) kandydat na dawcę został przed wyrażeniem zgody uprzedzony o skutkach dla biorcy wynikających z wycofania zgody na pobranie komórek, tkanek lub narządu, związanych z ostatnią fazą przygotowania biorcy do dokonania ich przeszczepienia;

9) kandydat na biorcę został poinformowany o ryzyku związanym z zabiegiem pobrania komórek, tkanek lub narządu oraz o możliwych następstwach pobrania dla 
m.in. pobranie zostało poprzedzone niezbędnymi badaniami lekarskimi ustalającymi, czy ryzyko zabiegu nie wykracza poza przewidywane granice dopuszczalne dla tego rodzaju zabiegów i nie upośledzi w istotny sposób stanu zdrowia dawcy.

Jednak kluczową kwestią z punktu widzenia rozważanej tu problematyki wydaje się problem opisany w art. 9, który stanowi, iż ,pobranie komórek, tkanek lub narządów do przeszczepienia jest dopuszczalne po stwierdzeniu trwałego nieodwracalnego ustania czynności mózgu ('śmierci mózgu)". Dodać trzeba, iż nieodwracalne ustanie czynności mózgu stwierdza jednomyślnie, na podstawie kryteriów zamieszczonych w obwieszczeniu Ministra Zdrowia, komisja złożona z trzech lekarzy, posiadających specjalizację, w tym co najmniej jednego specjalisty w dziedzinie anestezjologii i intensywnej terapii oraz jednego specjalisty w dziedzinie neurologii lub neurochirurgii. W obwieszczeniu Ministra Zdrowia z dnia 17 lipca 2007 r. w sprawie kryteriów i sposobu stwierdzenia trwałego nie-

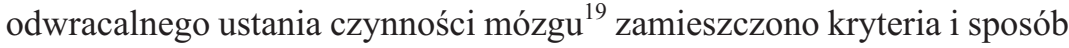
stwierdzenia trwałego nieodwracalnego ustania czynności mózgu, ustalone przez specjalistów z dziedzin medycyny: anestezjologii i intensywnej terapii, neurologii, neurochirurgii oraz medycyny sądowej, stanowiące załącznik do obwieszczenia. Wyjaśniono tu, iż „Śmierć jest zjawiskiem zdysocjowanym. Oznacza to, że śmierć ogarnia tkanki i układy w różnym czasie. Powoduje to dezintegrację ustroju jako całości funkcjonalnej i kolejne, trwałe wypadanie poszczególnych funkcji w różnej sekwencji czasowej. Zatem niektóre funkcje ustroju lub ich części mogą utrzymywać się przez pewien czas w oderwaniu od innych, wcześniej obumarłych. Zdysocjowany charakter zjawiska ujawnia się w sposób szczególny w sytuacjach, w których śmierć objęła już mózg, podczas gdy krążenie krwi jest jeszcze zachowane. W tych przypadkach to stan mózgu determinuje życie lub śmierć człowieka. W większości przypadków klinicznych obrzęk mózgu wynikający z jego uszkodzenia narasta od strony przestrzeni nadnamiotowej, a pień mózgu umiera jako ostatnia jego część. W takich sytuacjach czynnikiem kwalifikującym śmierć mózgu jest nieodwracalny brak funkcji pnia mózgu. Trwałe uszkodzenie pnia mózgu ustala się na

stanu zdrowia dawcy, a także wyraził zgodę na przyjęcie komórek, tkanek lub narządu od tego dawcy; wymóg wyrażenia zgody na przyjęcie przeszczepu od określonego dawcy nie dotyczy szpiku lub innych regenerujących się komórek i tkanek.

19 M. P. Nr 46, poz. 547. 
podstawie braku określonych odruchów nerwowych i braku spontanicznej czynności oddechowej. Postępowanie takie, oparte przede wszystkim na badaniach klinicznych, w przeważającej liczbie przypadków jest możliwe, a jego wynik - pewny. W szczególnych okolicznościach badanie odruchów nerwowych nie jest jednak w pełni wykonalne (np. urazy twarzoczaszki), a ich interpretacja trudna (np. zatrucia, farmakoterapia). Co więcej, w pierwotnie podnamiotowych uszkodzeniach mózgu, jego śmierć wymaga szczególnego postępowania diagnostycznego, bowiem kliniczne objawy trwałego uszkodzenia pnia mózgu nie oznaczają w tym przypadku jednoczesnego nieodwracalnego uszkodzenia całego mózgu. W takich przypadkach podejrzenie śmierci mózgu musi być potwierdzone badaniami instrumentalnymi. [...] Wieloletnia praktyka medyczna jednoznacznie wykazała, że w wybranych przypadkach odstapienie od koncepcji śmierci człowieka jako całości na rzecz śmierci mózgu człowieka jako całości jest uzasadnione z naukowego i praktycznego punktu widzenia. W świetle postępu w medycynie i dynamicznego rozwoju intensywnej terapii takie stanowisko okazuje się być ze wszech miar potrzebne i słuszne. Pomimo ogromnych możliwości ratowania ludzkiego zdrowia i życia, jakie aktualnie posiada nowoczesna medycyna, istnieją granice ich stosowania. Jedną z nich jest śmierć mózgu" 20 .

Jak z powyższego wynika, to właśnie kryterium śmierci mózgowej jest decydujące w orzekaniu o śmierci człowieka. W takiej sytuacji, zważywszy na powyższe kryteria, z punktu widzenia prawa dokonanie przeszczepu mózgu jest niemożliwe. Byłoby to przecież możliwe tylko w sytuacji nieodwracalnej śmierci mózgu. A nie ma możliwości ponownego „ożywienia" takiego mózgu.

Z tego też punktu widzenia, rozstrzygając postawione na wstępie pytanie, należałoby stwierdzić, że w istocie samo pojęcie przeszczepu mózgu jest niewłaściwe. Skoro prawna podmiotowość człowieka związana jest z mózgiem, to należałoby mówić raczej o transplantacji „opakowania mózgu".

Nawet jeżeli udałoby się pokonać dzisiejsze bariery technologii medycznej, a także przeszkody prawne, o których nowa była powyżej (konieczne byłoby zatem zredefiniowanie śmierci człowieka i sięgnięcie po inne kryteria, bądź uczynienie wyjątków), konsekwencje takiego przeszczepu mogą być trudne do przewidzenia. I to właściwie na każdej płasz-

20 Ibidem. 
czyźnie, również na gruncie każdej gałęzi prawnej. Chodzi tu zwłaszcza o ustalenie „siedliska” podmiotowości prawnej (choć nie tylko) człowieka. I tak z punktu widzenia prawa cywilnego pojawić mogą się wątpliwości, chociażby kto jest osobą fizyczną. Przypomnieć w tym miejscu należy, iż istotne znaczenie ma tu art. 8. § 1 kodeksu cywilnego, zgodnie z którym każdy człowiek od chwili urodzenia do momentu śmierci ma zdolność prawną ${ }^{21}$, jest zatem podmiotem prawa. W kontekście rozważanej tu problematyki może pojawić się wątpliwość, kto jest tym podmiotem. Oczywiście twórcy art. 8 k.c. nie musieli takiego dylematu rozstrzygać. Powracamy zatem znów do kwestii, czy podmiotowość jest związana z mózgiem czy ciałem. Jak już wyżej sygnalizowano wydaje się, że ten dylemat trzeba rozwiązać biorąc pod uwagę, iż obecnie właściwie istotę człowieczeństwa utożsamia się właśnie z mózgiem. Trzeba tu jednak od razu dodać, że to właściwie tylko dla celów transplantacji tak orzeczono z powodów pragmatycznych. Ale tak wcale być nie musi, o czym świadczą relacje transplantologów informujących o zmianach osobowości u pacjentów chociażby po transplantacji serca. Bo brzmi to rzeczywiście mało przekonywująco, iż podmiotowość jednostki związana jest z jednym tylko organem. A przesądzenie tej kwestii może mieć niezwykle istotne znaczenie właściwie w każdym aspekcie prawa cywilnego, zarówno, gdy chodzi o prawo spadkowe, jak i rzeczowe. Nie mniejsze wątpliwości mogą pojawić się na płaszczyźnie prawa rodzinnego, w szczególności praw rodzicielskich, relacji mąż-żona, rodzic-dzieci. Wątpliwości mogą pojawić także na gruncie prawa karnego. Mianowicie, co będzie odpowiedzialne za popełnienie przestępstwa: mózg czy pozostałe ciało. Dotyczy to także odbywania kar, a w szczególności kary pozbawienia wolności. Jednak już techniki identyfikacji osób podejrzanych będą z pewnością zawodzić. Chodzi w szczególności o badanie linii papilarnych, a także DNA. Podobne rozterki z pewnością pojawią się na płaszczyźnie prawa konstytucyjnego (praw wyborczych itp.), administracyjnego, ale także na każdej innej.

Wydaje się, że w każdej z rozważanych sytuacji, z powodów pragmatycznych należy konsekwentnie utrzymać powyższą zasadę tożsamości podmiotowej związanej z mózgiem. I właściwie z punktu widzenia prawa można sobie z tym poradzić. Sytuacja jednak się skomplikuje, jeżeli dojdzie tylko do częściowego przeszczepu mózgu. W takim bowiem przypadku, powyższe ustalenia okażą się całkowicie zawodne.

21 Pominąć tu należy kwestię warunkowej zdolności prawnej nasciturusa. 
Natomiast pokuszenie się o prognozy, jakie mogą być konsekwencje społeczne jest właściwie niemożliwe. Podobnie, jak udane przeprowadzenie takiego eksperymentu na człowieku. Z ostrożności badawczej wypada powiedzieć „na razie”. Być może jednak, z uwagi na powyższe dylematy, z punktu widzenia deontologicznego należałoby takich zabiegów zabronić, argumentując, iż następuje tu niedopuszczalna ingerencja w osobowość człowieka. Przecież normy etyczne i prawne nie pozwalają dzisiaj na „wszystko” co „technicznie” medycyna pozwala osiaggnąć.

Z drugiej strony jednak, gdyby zastosować odmienną terminologię, a mianowicie ustalić, jak to wyżej próbowano opisać, iż mamy tu do czynienia nie z transplantacją mózgu, a pozostałych organów, to wydźwięk etyczny będzie złagodzony. Bo skoro dzisiaj dopuszcza się właściwie bez żadnych zastrzeżeń natury aksjologicznej pobranie nerki, serca, płuc itd., to „transplantacja ciała” do mózgu nie będzie już wzbudzać takich wątpliwości. Wydaje się jednak, że ta perspektywa jest ciagle na tyle odległa, iż nie musimy się na razie niepokoić czy i kiedy nastąpi w tym kontekście „koniec człowieka”,22.

\section{Summary}

The objective of the paper concerns the legal, social and ethical consequences of the technological progress in medicine which we are (or soon will be) witnessing, even if at present they appear to be quite futuristic. In order to demonstrate the essence of the problem the author focuses on a single aspect of this medical and technical 'revolution', i.e. the possibility of brain transplantation that will soon be feasible. It should be mentioned right at the beginning that other aspects of medical progress, such as assisted procreation, cloning, genetic engineering and the application of some psychotropic drugs are just as controversial from the deontological or legal point of view. It needs to be admitted that apart from affecting individual lives, medical revolution may also have political results, involving for example the possibility of the intentional change of human nature.

22 F. Fukuyama, op. cit., passim. 
